University of Arkansas, Fayetteville

ScholarWorks@UARK

Education Reform Faculty and Graduate

Students Publications

4-23-2019

\title{
Do You Get Cream with Your Choice? Characteristics of Students Who Moved into or Out of the Louisiana Scholarship Program
}

\author{
Yujie Sude \\ University of Arkansas, Fayetteville \\ Patrick J. Wolf \\ University of Arkansas, Fayetteville
}

Follow this and additional works at: https://scholarworks.uark.edu/edrepub

Part of the Educational Assessment, Evaluation, and Research Commons, Educational Leadership Commons, and the Other Educational Administration and Supervision Commons

\section{Citation}

Sude, Y., \& Wolf, P. J. (2019). Do You Get Cream with Your Choice? Characteristics of Students Who Moved into or Out of the Louisiana Scholarship Program. Education Reform Faculty and Graduate Students Publications. Retrieved from https://scholarworks.uark.edu/edrepub/80

This Article is brought to you for free and open access by the Education Reform at ScholarWorks@UARK. It has been accepted for inclusion in Education Reform Faculty and Graduate Students Publications by an authorized administrator of ScholarWorks@UARK. For more information, please contact scholar@uark.edu. 


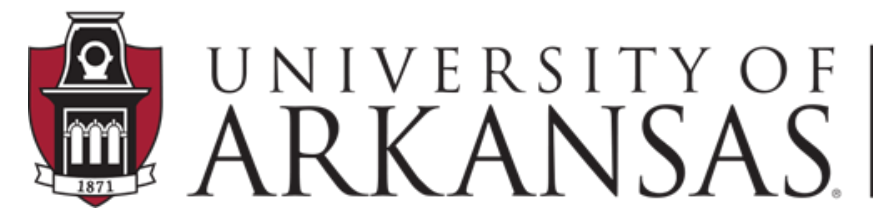

College of Education \& Health Professions Education Reform

\author{
WORKING PAPER SERIES
}

\title{
DO YOU GET CREAM WITH YOUR CHOICE? CHARACTERISTICS OF STUDENTS WHO MOVED INTO OR OUT OF THE LOUISIANA \\ SCHOLARSHIP PROGRAM
}

Yujie Sude and Patrick J. Wolf

April 23, 2019

EDRE Working Paper 2019-13

The University of Arkansas, Department of Education Reform (EDRE) working paper series is intended to widely disseminate and make easily accessible the results of EDRE faculty and students' latest findings. The Working Papers in this series have not undergone peer review or been edited by the University of Arkansas. The working papers are widely available, to encourage discussion and input from the research community before publication in a formal, peer reviewed journal. Unless otherwise indicated, working papers can be cited without permission of the author so long as the source is clearly referred to as an EDRE working paper. 


\title{
DO YOU GET CREAM WITH YOUR CHOICE? CHARACTERISTICS OF STUDENTS WHO MOVED INTO OR OUT OF THE LOUISIANA SCHOLARSHIP PROGRAM
}

\author{
Yujie Sude \\ Economics Department \\ Sam M. Walton College of Business \\ University of Arkansas \\ Fayetteville, AR 72701 \\ ysude@uark.edu \\ Patrick J. Wolf \\ Department of Education Reform \\ University of Arkansas \\ Fayetteville, AR 72701 \\ pwolf@uark.edu
}

Louisiana Scholarship Program Evaluation Report \#13

April 23, 2019

School Choice Demonstration Project, University of Arkansas, Fayetteville, AR

\section{Acknowledgments}

We thank the Smith Richardson Foundation for financial support for this research. We gratefully acknowledge Gema Zamarro, Robert Anthony Maranto, Douglas Harris, Jonathan N. Mills for their extensive helpful comments on previous drafts as well as the Louisiana Department of Education for their cooperation and assistance with providing the necessary data to conduct the analyses. We are grateful to Kathleen Wolf for editorial help. The content of the report is solely the responsibility of the authors and does not necessarily represent the views of the University of Arkansas, Tulane University, the Louisiana Department of Education, or the Smith Richardson Foundation.

* Corresponding author. Address 415B Business Building, Fayetteville, AR 72701; Tel.:1-479-575-7409;

E-mail address: ysude@uark.edu 


\begin{abstract}
Private school choice programs often are accused of failing to serve disadvantaged students. Critics claim that participating private schools "skim the cream off the top" by admitting only the best students and "push out" students who are the most difficult to teach. This study tests these student selection hypotheses in the context of the Louisiana Scholarship Program (LSP). We find LSP applicants are less advantaged than their public school peers regarding their family socioeconomic status and initial test scores. No consistent evidence indicates that the LSP private schools are "skimming the cream" or "pushing out" students based on their family social status or initial test scores. However, students with disabilities are less likely than students without disabilities to use a voucher initially. Students who were placed in LSP private schools that were farther from their homes or that serve a larger minority population are more likely to leave their LSP schools than LSP students placed in schools closer to their homes or that serve smaller minority populations. LSP students with better educational resources in their residential public school district are more likely to leave the LSP than students with worse educational resources. Finally, the LSP students still using vouchers after three years are more likely to have a low family income, more likely to be African American, and more likely to be female than the population of non-applicants to the program.
\end{abstract}

Keywords: school choice, school movement, cream skimming, student selectivity, survival model 


\section{DO YOU GET CREAM WITH YOUR CHOICE? CHARACTERISTICS OF STUDENTS WHO MOVED INTO OR OUT OF THE LOUISIANA SCHOLARSHIP PROGRAM}

In the U.S., some education policy analysts recommend school choice programs as remedies for a public education system perceived to be ineffective. Supporters of school choice programs state that such programs will help improve student educational achievement, especially for those who come from disadvantaged backgrounds, by (1) providing access to objectively better schools and (2) allowing parents to choose the school which is most suitable for their child (DeAngelis \& Erickson, 2018; Chubb \& Moe, 1990; Friedman,1962, 1955).

Critics, on the other hand, argue that choice programs lure the best students away from current public schools, which results in a negative "cream skimming" effect that disadvantages those who remain behind (Altonji, Huang, \& Taber, 2015). Even when program applicants are admitted to choice-schools under random lotteries, relatively disadvantaged students tend to be "pushed out" of choice programs at a disproportionally higher rate than their more advantaged peers, critics claim (Mincberg, 2003). "Cream skimming" and "pushing out" threaten the equity goals of expanded parental school choice.

This perceived selection issue also raises concerns when interpreting the effects of choice programs. Lottery-based school choice evaluations are the most appealing approach to estimating the true effects of a school choice program (Pirog, 2014; Wolf et al., 2013; Boruch, Moya, \& Snyder, 2002). Random assignment enables researchers to obtain unbiased program effects simply by comparing the average outcomes of the treatment and control groups. However, families can self-select out of a choice program by either declining to use it when it is offered or by leaving the choice school after initially attending. Such self-selections violate the "random" 
assumption of field experiments (Barnard et al. 2003) thus challenging the internal validity of program evaluation. Though conservative approaches such as intent-to-treat (ITT) analysis and econometric techniques like Instrument Variable (IV) or Complier Average Causal Effect (CACE) models account for selection and therefore preserve the internal validity of experiments, the fact that program effects on non-compliers are never actually observed limits the external validity of the results (e.g. Cowen, 2008; Howell \& Peterson 2006).

A systematic pattern of program attrition also could indicate that the program is not serving a targeted student population. Policy makers want to know if an intervention is serving key subgroups of students and for whom such an intervention is most promising. Knowledge about program non-compliers also signals potential barriers that are preventing targeted families from fully participating in the program.

As school choice programs proliferate and expand, student selection issues are particularly important. So far, evidence from small-scale privately-funded voucher programs in Charlotte (NC), Cleveland (OH), New York City (NY), and publicly-funded voucher programs in Milwaukee (WI), Washington (DC) and Ohio provide informative yet inconsistent patterns of program "cream skimming" and the "pushing out" of students based on their demographics (Figlio \& Karbownik, 2016; Fleming et al., 2015; Figlio, 2014; Carlson et al., 2013; Cowen et al., 2012; Cowen, 2010; Figlio, Hart, \& Metzger, 2010; Wolf, Eissa, \& Gutmann, 2006; Campbell et al., 2005; Howell, 2004; Rouse, 1998). There is little evidence of consistency in the patterns of students' participation in private school choice programs, demographically and institutionally.

This study identifies which factors influence students' participation in the first three years of the Louisiana Scholarship Program (LSP): school years 2012-13 to 2014-15. The LSP is one 
of the nation's first statewide private school choice programs that offers publicly funded vouchers to cover private school tuition for students from low-income families whose children previously attended low-performing public schools. Initially established in 2008 as a pilot program in New Orleans, the LSP was expanded statewide in the 2012-13 school year. LSP placements are based on school-grade level lotteries while first accounting for student priorities.

We specifically examine what factors predict students' applying to the LSP, participating students' self-selecting out of the program by declining to use a voucher offered to them, and students' withdrawing from the LSP. Factors examined include student demographics, specific attributes of assigned private schools, residential school district educational resources, and the institutional attributes of the public schools students attended during the baseline year prior to applying to the LSP.

The paper proceeds as follows. In the next section, we review the research literature on student participation patterns in private school choice programs in the U.S., followed by a description of the subject of our study, the LSP. We then present our research methodology, including the data and analytical strategy we use in this study. The following section presents the main findings. Our final section concludes with policy implications.

\section{Prior Studies on Student Participation in Private School Choice Programs}

Empirical studies have examined student participation in voucher and voucher-type scholarship programs that target disadvantaged students in Charlotte (NC), Florida, Milwaukee (WI), Ohio, New York City (NY), and Washington (DC).

Most voucher programs have been targeted to students coming from low-income families, students with disabilities, or students with other disadvantages. The New York City voucher program, funded privately by the School Choice Scholarship Foundation (SCSF), had a 
greater proportion of African American applicants and a lower non-Hispanic white population, as well as a larger proportion of welfare recipients, in the applicant group than in the nonapplicant group (Howell, 2004). Students with disabilities, who were African American, or who were enrolled in the Free/Reduced price Lunch program applied to the DC Opportunity Scholarship Program in numbers that exceeded their share of the DC school population (Wolf, Eissa, \& Gutmann, 2006). In the privately-funded national Children's Scholarship Fund (CSF) program, Campbell, West, and Peterson (2005) found that African American and Hispanic parents, as well as mothers with higher levels of education, tended to have a higher likelihood of applying for the voucher when compared to non-applicants.

Voucher programs targeted to low-income families may vary in the rates at which students actually use their vouchers. In New York City's SCSP, nearly $26 \%$ of students declined to use their vouchers to attend private schools during the program's first year (Howell, 2004). The decline rates were similar in other privately funded programs such as the Children's Scholarship Fund (CSF) in Charlotte, NC, where $24 \%$ of the voucher lottery winners declined to use a voucher initially (Cowen, 2010). In the first federally funded voucher program in Washington, DC, 25\% of the lottery winners failed to use a voucher in the first year (Wolf, Eissa, \& Gutmann, 2006).

Who are those decliners? No consistent "cream skimming" has been found across these programs based on student test scores.Evidence from New York (Howell, 2004); Washington, DC (Wolf, Eissa, \& Gutmann, 2006); and Ohio (Figlio \& Karbownik, 2016) suggests that relatively low-achieving students are more likely to decline an awarded voucher, while Florida (Hart, 2014; Figlio, Hart, \& Metzger, 2010) presents evidence of higher-performing students being less likely to use the voucher-type tax-credits to attend private schools. 
Student demographics also predict voucher usage. Males, African Americans, Hispanics, and students with special educational needs are more likely to decline a voucher when offered (Fleming et al., 2013; Cowen, 2010; Wolf, Eissa, \& Gutmann, 2006; Campbell, West, \& Peterson, 2005; Howell, 2004). Lower socioeconomic status, which includes families with a lower household income, a lower maternal educational level, and a larger family size, tends to increase the likelihood of students declining a voucher award (Fleming et al., 2013; Wolf, Eissa, \& Gutmann, 2006; Howell, 2004). Meanwhile, voucher decliners in the DC Opportunity Scholarship Program (DC OSP) and the Milwaukee Parental Choice Program (MPCP) tend to have higher residential stability (Fleming et al., 2013; Wolf, Eissa, \& Gutmann, 2006). Location is also an important consideration for voucher usage, as parents who decline vouchers in New York City, Dayton $(\mathrm{OH})$, and Washington (DC) claim the inconvenient locations of preferred private schools are a barrier to utilize the voucher (Howell et al., 2006).

Few scholars have examined the effects of public school resources on persuading students to decline a voucher. Campbell, West, and Peterson (2005) find that the attributes of a student's residential school district appear to influence school choice decisions. Students from districts with higher proportions of minority students, lower educational expenditures, and lower private school density tend to be more likely to decline to use a voucher.

Students also can opt out of a school choice program after initially using a voucher. Descriptively, there is substantial evidence that students who attend private schools using a voucher tend to opt out at high annual rates. In Milwaukee, the program attrition rate has ranged from $22 \%$ to $35 \%$ every year (Carlson et al., 2013; Cowen et al., 2012; Rouse, 1998). In New York City, this rate has been about $22 \%$ annually (Howell, 2004). In the most recent statewide voucher program, the Indiana Choice Scholarship Program, 16.3\% of the voucher users exited 
the program after the first year (Waddington \& Berends, 2018). The private school attrition rates in voucher programs are similar to student mobility rates in public schools. The Institute of Medicine and National Research Council (2010) reported that in 1998 roughly 33\% of $4^{\text {th }}$ graders, $20 \%$ of $8^{\text {th }}$ graders, and $10 \%$ of $12^{\text {th }}$ graders had changed schools at least once in the previous two years, and this rate is generally high in large urban districts populated disproportionally by minority students.

Studies of students who stop attending private schools in choice programs present a clear pattern. Students who struggle in private schools academically leave the program at higher rates (Figlio et al., 2014; Carlson et al., 2013; Cowen et al., 2012; Rouse, 1998). Students who exit private school choice programs are more likely to be minorities, in higher grade levels (Carlson et al., 2013; Cowen et al., 2012; Howell, 2004;), with lower residential stability (Howell, 2004), and lower family income (Cowen et al. 2012; Howell, 2004; Rouse, 1998) than students who persist in the programs. These attrition characteristics also describe students with educationally disadvantaged backgrounds who were originally targeted by the programs. Cowen et al. (2012) further find that students who previously attended private schools with a larger share of minority students or voucher students tend to have a higher likelihood of returning to the public education system.

In sum, students who come from disadvantaged families tend to be more likely to apply for private school vouchers, however, even among applicants, relatively disadvantaged are more likely to decline a voucher once offered. Even after accepting the voucher, these students are more likely to transfer back to public schools. No consistent evidence on school cream skimming based on test scores has been found. However, lower-achieving students face a greater risk of leaving private school choice programs. We do not know if these patterns of voucher declining 
and voucher program attrition exist because more disadvantaged students are somehow prevented from attending private schools, "counseled out" of them once they are there, or voluntarily leave the program. It is at least possible that some families, both disadvantaged and advantaged, have a higher preference for public schooling even when the opportunity for private schooling is offered to them or after personally experiencing private schooling.

\section{Background: The Case of the Louisiana Scholarship Program}

Currently, 30 states and the District of Colombia have adopted at least one private school choice program (EdChoice, 2019). Most of these choice programs are limited to urban areas or to students with disabilities. The Louisiana Scholarship Program (LSP) is one of the first statewide private school choice programs that offers publicly funded vouchers to cover private school tuition for students from low-income families who previously attended low-performing public schools. Initially established in 2008 as a pilot program in New Orleans, the LSP was expanded to a statewide program during the 2012-13 school year. Students with a family income of less than $250 \%$ of the federal poverty line who are entering kindergarten or who previously attended public schools graded C, D, or $\mathrm{F}^{1}$ are eligible for LSP vouchers. In the first year of program expansion, 2012-13, 41\% of the K-12 student population was eligible for this voucher program, 9,809 eligible students applied for the scholarship, and 5,771 of them ( $0.82 \%$ of the K-12 student population) received a voucher worth on average $\$ 5,242$. The voucher amount is $90 \%$ of the combined state and local foundation aid to the student or the tuition amount charged by the chosen private school, whichever is less.

\footnotetext{
${ }^{1}$ School Grades in Louisiana's school accountability system at baseline year (2011-12).
} 
Several features differentiate the LSP from most other voucher programs. Private schools must accept the LSP voucher amount as the full cost of educating the child and cannot require that parents "top-up" the voucher value. Further, eligible students are assigned the voucher for a specific grade in a particular school under a lottery mechanism accounting for their service priorities. Specifically, students with disabilities and "multiple birth siblings" (e.g. twins or triplets) automatically receive a scholarship if there is an available space at their preferred school. Finally, participating LSP private schools cannot apply admission standards to voucher students based on their family socio-economic status or test scores. These factors limit the schools' ability to enroll students selectively.

Applicants to the LSP can list up to five private schools on a tiered preference in their application. This design feature could increase parents' probability of taking up the voucher because its award coincides with placement in a school requested by the parents, often their firstor second-choice school (Abdulkadiroğlu, Pathak, \& Roth, 2005; Abdulkadiroğlu et al., 2005).

Students in Louisiana tend to have many schooling options. The charter school sector is large in Louisiana, especially in the urban areas of New Orleans and Baton Rouge (Wolf \& Lasserre-Cortez, 2018). Various public school choice programs, including magnet schools and charter schools, pre-dated the LSP and enrolled $30 \%$ of LSP applicants. Nearly $20 \%$ of K-12 students in the state pay tuition to attend private schools. Since parents in Louisiana have more schooling options, we may expect higher decliner and attrition rates in the LSP, compared to other voucher programs, especially in the districts with a higher density of charter and magnet schools.

Lastly, studies reveal that the private schools participating in the LSP tend to be below average in school quality. Only one-third of the private schools in Louisiana enroll LSP students. 
Those LSP schools tend to have lower tuition costs and smaller enrollments than the average Louisiana private school, both of which are indicators of lower quality schools (Sude, DeAngelis, \& Wolf, 2018). Further, Mills and Wolf (2017) show that voucher-awarded students fell significantly behind their peers academically in public schools during the first two years of the program; however, this difference became statistically null by the third year. This pattern suggests that the private schools participating in the LSP failed to improve student academic achievement, especially for the first two years. Thus, we expect many LSP students to have made a strategic move to leave the program before the third year, especially those from relatively more advantaged families who are better able to obtain a quality education for their children.

This study aims to further the literature about student participation in voucher programs by analyzing student participation patterns during the first three years of the LSP. We test for systematic initial cream skimming or later attrition based on student demographics, family backgrounds, and test scores.

\section{Data and Sample}

The data we analyze come from the LSP eligible applicant, Student Information System (SIS), and State Assessment files. The Louisiana Department of Education (LDE) provided these student-level restricted use files according to our data agreement with the state.

\section{Data description}

The major outcome of interest of our study is student voucher usage status in the Louisiana Scholarship Program. We obtained this information from the LSP eligible applicant file. Voucher usage status is tracked by fiscal quarters ${ }^{2}$ and a student is recorded as " 1 " in quarter

\footnotetext{
${ }^{2}$ For instance, in school year 2012-2013, Quarter 1 denotes the time period of July, August, and September 2012, Quarter 2 denotes the time period of October, November, and December 2012, Quarter 3 denotes the time period of January, February, and March 2013, and Quarter 4 denotes the time period of April, May, and Jun 2013.
} 
Q for usage if she or he has used the voucher to attend a private school in Louisiana during Q.

The LSP eligible applicant file also provides information on student individual demographics, such as gender, ethnicity, and grade level; eligible applicant's school choice list; and lottery placement in the baseline year. Since parents were not required to report their household income and educational levels for application, we obtained the Neighborhood Average Household Income $^{3}$ associated with the applicant's zip code to proxy for family socio-economic status (SES).

Student movement among Louisiana schools is another consideration. We obtained this information from the Student Information System (SIS) files for the baseline year of fiscal 201112 through outcome year three in 2014-15. These data provide student enrollment records prior to and after participating in the LSP, enabling us to identify if and when a voucher user has returned to a public school during the period July 2011 through June 2015.

We merge our dataset with students' state assessment records on math achievement from the baseline year 2011-12 through 2014-15 to explore if usage patterns are related to student annual achievement. Students in Louisiana are required to take state assessments in grades three through eight unless excused due to a disability. The exams are criterion-referenced tests that align with Louisiana's state standards. The tests produce scale scores between 100 and 500 with a mean of 300 and a standard deviation of 50. To better compare students' test scores over time and grade levels, we convert these scale scores into standardized z scores by grade level. By including baseline or current student test scores, we restrict our analytical sample to only elementary students in grades three through eight in 2012-13 with test scores.

\footnotetext{
${ }^{3}$ IRS, Statistics of Income Division, Individual Master File System, July 2014.
} 
In addition to the data sets provided by the LDE, we also collect information on the private schools $^{4}$ that receive voucher students during school year 2012-13 through 2014-15. The private school characteristics include the ethnicity of the student population, school tuition, and the number of voucher students enrolled in the first year after statewide program expansion. We also estimate the distance between the assigned private school and the student's home by estimating the general distance between school and home zip $\operatorname{codes}^{5}$ to proxy for the convenience of attending the lottery-assigned private school.

For the analyses of voucher usage during the post-lottery period, we restrict our analysis to the initial 2012-13 cohort of program applicants and scholarship recipients. Furthermore, we assume that parental choices for kindergarteners, who may be entering school for the first time, are different from those for students in higher grades. Most of the rising kindergarten students lack information about their previous public school attended, since there was none. Therefore, we exclude all kindergarten applicants from our analysis.

Table 1 describes our analytical samples. When the program was launched in the 2012 school year, 7,747 non-kindergarten students applied for the program, and 4,426 of them were offered the voucher that year, among which 3,865 have ever used the voucher to enroll in a private school in the next 3 years. By the end of the third year of the program, we observe 1,669 voucher users in our sample, which includes 527 students who were in grades 3 through 5 in the initial application.

\footnotetext{
${ }^{4}$ Private School Universe Survey (PSS) (2011-12 and 2013-14).

${ }^{5}$ Zip code distances were obtained from the ZIP Code Tabulation Area (ZCTA) Distance Database, NBER. http://www.nber.org/data/zip-code-distance-database.html
} 
Table 1

Sample Description

\begin{tabular}{lr}
\hline Sample Description & Counts (N) \\
\hline Non-applicants & 689,760 \\
Applicants & 7,747 \\
Offered LSP voucher & 4,426 \\
Ever User (Overall Sample) & 3,865 \\
Ever User (Students in Grades 3 through 5 in 2012) & 1,196 \\
Voucher User in Year 3 (Overall Sample) & 1,669 \\
Voucher User in Year 3 (Students in Grades 3 through 5 in 2012) & 527 \\
\hline
\end{tabular}

Notes: Counts based on non-kindergarten students in the year 2012-13, with and without restricting the sample to students in grades 3 through 5 in 2012.

\section{Student demographics}

Table 2 presents the descriptive statistics of the students' demographics and characteristics of the public schools they previously attended. Voucher awardees are overwhelmingly African American (88\%), in elementary grades (82\%), and from traditional public schools (TPS) (74\%). Only $6 \%$ of the awardee-students are classified as having a disability, $4 \%$ have multi-birth siblings (i.e. twins, triplets, etc.), and 38\% previously participated in the LSP Pilot program. More than $90 \%$ of students awarded scholarships were placed in their first-choice schools.

Table 3 presents descriptive statistics of student characteristics including students' baseline achievement, family background, attributes of their lottery-assigned private schools, and the community educational resource of their residential school district. Only 1,953 students have baseline test scores, with an average $\mathrm{z}$-score of -0.54 , indicating relatively low-achieving students in our sample compared to the state population. Students' family background information provided by the scholarship application files merely includes family residential address. We connect students' associated zip codes with the Neighborhood Mean Household 
Incomes provided by the IRS to proxy for their family socio-economic status. On average, LSP awardees' neighborhood household income in 2012 was around \$46,600.

Table 2

Individual and Baseline School Characteristics of Voucher Awarded Students (2012)

\begin{tabular}{|c|c|c|c|c|}
\hline \multirow[b]{2}{*}{ Variable } & \multicolumn{2}{|c|}{ Overall Sample } & \multicolumn{2}{|c|}{ Students in Grade 3 through 5 (2012) } \\
\hline & Count & $\%$ & Count & $\%$ \\
\hline Student Characteristics & \multicolumn{2}{|c|}{$(\mathrm{N}=4,426)$} & \multicolumn{2}{|c|}{$(\mathrm{N}=1,382)$} \\
\hline Female & 2,244 & 50.7 & 674 & 48.8 \\
\hline African American & 3,893 & 88.0 & 1,228 & 88.9 \\
\hline Hispanic & 109 & 2.5 & 29 & 2.1 \\
\hline Caucasian and Other Races & 424 & 9.6 & 125 & 9.0 \\
\hline Special Education Need & 270 & 6.1 & 102 & 7.4 \\
\hline Elementary (Grades 1-6) & 3,616 & 81.7 & 1,382 & 100.0 \\
\hline Middle School (Grades 7-9) & 668 & 15.1 & 0 & 0.0 \\
\hline High School (Grades 10-12) & 145 & 3.2 & 0 & 0.0 \\
\hline Multiple Birth Siblings & 175 & 4.0 & 41 & 3.0 \\
\hline NOLA Participant & 1,673 & 37.8 & 503 & 36.4 \\
\hline Awarded Voucher to $1^{\text {st }}$ Choice School & 4,045 & 91.4 & 1,262 & 91.3 \\
\hline Previously Attended School ${ }^{a}$ & \multicolumn{2}{|c|}{$(\mathrm{N}=2,781)$} & \multicolumn{2}{|c|}{$(\mathrm{N}=885)$} \\
\hline Charter School & 544 & 19.6 & 184 & 20.8 \\
\hline Magnet School & 175 & 6.3 & 40 & 4.5 \\
\hline TPS School & 2,064 & 74.1 & 661 & 74.7 \\
\hline
\end{tabular}

Notes: Counts based on non-kindergarten students who were awarded LSP vouchers in the year 2012-13, with and without restricting the sample to students in grades 3 through 5 in 2012. ${ }^{\text {a }}$ SOURCE: IES-NCES national center for education statistics, Common Core of Data (CCD) Local Education Agency (School District) Universe Survey Data, 2011-12, LA. 
Table 3

Family Background, Community Educational Resources, and Awarded Private School Characteristics of Voucher Awarded Students (2012)

\begin{tabular}{|c|c|c|c|c|c|c|}
\hline & \multicolumn{3}{|c|}{ Overall Sample } & \multicolumn{3}{|c|}{$\begin{array}{c}\text { Students in Grade } 3 \\
\text { through } 5\end{array}$} \\
\hline & Obs. & Mean & $\begin{array}{l}\text { Std. } \\
\text { Dev. }\end{array}$ & Obs. & Mean & $\begin{array}{l}\text { Std. } \\
\text { Dev. }\end{array}$ \\
\hline Student Achievement at the Base Line & & & & & & \\
\hline Math Achievement & 1,953 & -0.54 & 0.94 & 1,323 & -0.54 & 0.92 \\
\hline Family Background & & & & & & \\
\hline Neighborhood Mean Household Income $(\$ 1,000)^{a}$ & 4,421 & 46.63 & 22.84 & 1,380 & 47.02 & 22.68 \\
\hline Awarded Private School & & & & & & \\
\hline Count of Voucher Students & 3,618 & 130.13 & 99.35 & 1,150 & 128.91 & 92.92 \\
\hline Private School Minority Enrollment (\%) b & 3,601 & 73.81 & 33.04 & 1,150 & 73.68 & 33.26 \\
\hline Tuition Rate $(\$ 1,000)$ & 3,601 & 5.41 & 1.67 & 1,150 & 5.21 & 1.59 \\
\hline Distance to Home (mile) & 3,585 & 5.19 & 5.97 & 1,144 & 5.21 & 6.15 \\
\hline Community Educational Resources ${ }^{c}$ & & & & & & \\
\hline Per-pupil Expenditure $(\$ 1,000)$ & 2,314 & 12.61 & 3.82 & 751 & 12.70 & 4.02 \\
\hline Count of Charter School & 2,353 & 2.67 & 3.24 & 767 & 2.30 & 2.95 \\
\hline District Minority Enrollment (\%) & 2,340 & 73.19 & 20.73 & 754 & 72.36 & 20.50 \\
\hline
\end{tabular}

Notes: Counts based on non-kindergarten students who were awarded LSP vouchers in the year 2012-13, with and without restricting the sample to students in grades 3 through 5 in 2012. ${ }^{\text {a }}$ SOURCE: IRS, Statistics of Income Division, Individual Master File System, July 2014. ${ }^{\text {b }}$ SOURCE: PSS Private School Universe Survey data 2012-13 and 2013-2014 school year. ${ }^{c}$ SOURCE: U.S. Department of Education National Center for Education Statistics Common Core of Data (CCD) "Local Education Agency (School District) Universe Survey” 2012-13 v.1a.

Since not all voucher-using students in our sample have test scores and associated schooling information, we categorize our sample into two groups by restricting it to students in grades 3 through 5 during the 2011-12 baseline year or not. Students in grades 3 through 5 in 2011-12 do not pass the $8^{\text {th }}$ grade during the three academic years following the baseline year. Thus, we have full information regarding their educational backgrounds including baseline test scores, outcome year test scores, and the associated schooling information. By restricting the analytical sample to only students in grades 3 through 5 in the baseline year, we are able to essentially eliminate the transition to high school as a possible explanation for moving to the public sector (Cowen et al., 2012). As a result, the overall sample comprises 4,426 voucher-using students, and the restricted sample includes 1,382 of those students. Descriptive statistics of the average student characteristics in these two analytical samples are mostly similar. The only 
exception is that we have only elementary students in the restricted sample, so it differs from the unrestricted sample regarding grade level.

\section{Analytical Strategy}

This study focuses on student participation during the first three years in the LSP. Who applied for the LSP initially? How do student backgrounds predict voucher decliners and users? What characteristics are associated with voucher attrition? Addressing these key research questions, we first compare the characteristics of families and students who applied for the program to those who did not, then compare the characteristics of families and students who declined vouchers to those who accepted them, and lastly compare the characteristics of families and voucher students who switch to public schools to those who remain. In this section, we make those comparisons for each factor while controlling for the effects of all the other factors on student usage patterns. Since our study focuses on students' post-lottery behaviors, this study is purely observational in design.

\section{Voucher application}

We first predict who applied for the voucher program. Student Information System (SIS) files recorded 695,812 students attending Louisiana public schools in the 2011 school year, of which 6,052 students applied to and were deemed eligible for the LSP.

We employ a Probit regression to estimate how students' backgrounds predict their LSP application $\left(y_{1}\right)$ with the value " 1 " indicating applicants and " 0 " for non-applicants. The decision of whether to apply or not apply for an LSP voucher is treated as a function of a latent variable, $Y_{1}^{*}$, which is a linear function of student demographics. If this latent variable's value is above a certain threshold, say 0 , the student decides to apply. If it is below that threshold, the student does not apply. Specifically, we model $Y_{1}^{*}$ and $y_{1}$ as: 


$$
\begin{array}{r}
y_{1}=\left\{\begin{array}{l}
1 \text { if } Y_{1}^{*}>0 \\
0 \text { if } Y_{1}^{*} \leq 0
\end{array}\right. \\
Y_{1}^{*}=\text { Student }_{i}^{\prime} \boldsymbol{\beta}+\varepsilon_{i c}
\end{array}
$$

Ideally the vector student would include a rich set of covariates. Unfortunately, due to data limitations, we are only able to compare basic student demographics between the two groups including gender, race, and Free/Reduced Price Lunch Program status. The non-applicant group includes both eligible and non-eligible students in order to test the extent to which the eligibility requirements of the program succeeded in targeting disadvantaged students.

\section{Voucher usage}

For the second research question, we are interested in students who were unable or unwilling to use the voucher when offered: the decliners. As summarized in Table 1, 3,865 of 4,426 LSP awardees have used the voucher to attend a private school during the 2012-13 to 2014-15 school years. The overall take-up rate for the first cohort non-kindergarten voucherawarded students is $87.3 \%$, indicating only one-eighth of students had never used a vouchersupported placement during the first three years of the LSP. This take-up rate is higher than other lottery-based voucher programs nationwide (Cowen, 2010; Wolf, Eissa, \& Gutmann, 2006; Howell, 2004;). The fact that students were simultaneously offered a voucher and placement in a specific preferred private school likely contributed to this high take-up rate (Abdulkadiroğlu, Pathak, \& Roth, 2005; Abdulkadiroğlu et al., 2005). The voucher take-up rate for the restricted sample is $86.6 \%$, which is not significantly different from the overall sample rate.

To account for the independent influence of specific student characteristics and educational background factors on the decliner decision, we use a Probit regression to estimate the effect of student background on parent behavior $\left(y_{2}\right)$ of taking (1) or declining (0) the 
voucher after initially receiving a voucher placement offer. The decision of whether to use or not use an LSP voucher is treated as a function of a latent variable, $Y_{2}^{*}$, which is a linear function of student demographics $\left(\right.$ Student $\left._{i}\right)$, characteristics of the private schools' students were placed to $\left(\right.$ Private $\left._{i}\right)$, residential school district educational resources $\left(\right.$ District $\left._{i}\right)$, institutional characteristics of previously attended public schools (PublicSchool $\left.{ }_{i}\right)$. If this latent variable's value is above a certain threshold, say 0 , the student decides to use. If it is below that threshold, the student does not to use. Specifically, we model $Y_{2}^{*}$ and $y_{2}$ as:

$$
y_{2}=\left\{\begin{array}{l}
1 \text { if } Y_{2}^{*}>0 \\
0 \text { if } Y_{2}^{*} \leq 0
\end{array}\right.
$$

$Y_{2}^{*}=$ Student $_{i}^{\prime} \cdot \boldsymbol{\beta}+$ Private School $_{i}^{\prime} \cdot \gamma+\operatorname{District}_{i}^{\prime} \cdot \delta+\operatorname{PublicSchool}_{i}^{\prime} \cdot \boldsymbol{\theta}+\varepsilon_{i c}$

Robust standard errors account for clustering of students within assigned private schools to account for spatial auto-correlation due to students placed in the same private school having the same private school characteristics and similar community educational resources.

\section{School movement}

Student school movement after attending the private school is another major outcome of interest in our study. We use the "leavers" to refer to voucher users who left the program after initially attending one at any time during the program. The leavers comprise two groups of students: those who went back to the public-school system and are recorded as enrolled in one public school in the SIS as public school returnees, and those who switched to another private school without using a voucher or who left Louisiana and thus are untraceable in the SIS. ${ }^{6}$ In our study, we focus both on the general leavers as well as the specific public school returnees.

\footnotetext{
${ }^{6}$ A student who switches to another LSP participating private school and continues to use his or her voucher is still identified as a "stayer" because the student has not left the program. If a voucher-using student switches to a nonLSP private school he or she will be coded as a "leaver" as his or her enrollment is not recorded in the SIS.
} 
Since student sector switching occurs across all three school years, student decisions regarding usage are best captured by a longitudinal decision-making model. We statistically model the patterns of student "survival" in the voucher program in the face of the "risk" that students will suffer the "hazard" of leaving the program during certain time periods. Students who leave the program at a specific point are not exposed to the risk of re-exiting the program at a later time. As a result, survival models are especially appropriate to estimate what kind of and to what extent the students' backgrounds influence their decisions regarding switching back to public schools during the school year 2012-13 through 2014-15 (Cox, \& Reid, 1984, 1-5).

We first estimate the unconditional hazard of switching sectors. Assuming the student using a voucher to attend a private school is exposed to the risk of exiting the program at a rate of:

$$
\mathrm{h}\left(t_{i j}\right)=\operatorname{Pr}\left(\mathrm{T}_{i}=\mathrm{j} \mid \mathrm{T}_{i} \geq \mathrm{j}\right)
$$

where $h(t)$ is the hazard rate of a voucher-using student leaving the program at the time $j$ conditional on remaining in the private school before time $j$. Once the student makes a crosssection movement in year $j$, the student will no longer be considered to be at risk. On average, the hazard function $\hat{h}(t)$ of leaving the program in period $j$ is calculated as:

$$
\hat{h}\left(t_{j}\right)=\frac{n \text { events }_{j}}{n \text { at risk }}
$$

Where $n$ events ${ }_{j}$ refers to the number of students who left the program during year $j$ and $n$ at risk $k_{j}$ represents the number of students remaining in private schools at the beginning of year $j$ (Singer \& Willett, 2003, p.332).

We first estimate the unconditional hazard of voucher usage in fiscal quarters during school years 2012-13 to 2014-2015 and graph the probability of staying in the voucher-accepting 
private schools as a Kaplan-Meier survival function in Figure 1. The figure clearly shows that the probability of staying in the LSP private schools decreases steadily during the 3-year time period in our study, with the biggest drops during summer sessions, between Quarter 4 of one fiscal year (April through June) and Quarter 1 of the next fiscal year (July through September). We further code student LSP annual voucher usage, focusing on the fall semester usage in Quarter 2 (October through December) of each school year. Any student observed as a "voucher user" in Quarter 2 of year $t$ while not observed as a user in Quarter 2 of year $t+1$ is recognized as a leaver in year $t$.

The hazard rate of annual-leaving among the original voucher users is presented in Table 4, including the count of students remaining in private schools at the beginning of each school year in Column 1 ( $n$ at risk $k_{j}$ ), and the count of students who left the program during each school year (Column 2). Hazard rates for users leaving LSP private schools in each year (Column 3) are obtained from Equation 4, and the cumulative Survivor Function (Column 4) is the proportion of students who remain in private schools accounting for the overall voucher users. Hazard rates of voucher-using students leaving the program are estimated for the overall sample and for the restricted sample, separately. We count leavers by school movement type in Columns 5 and 6. 


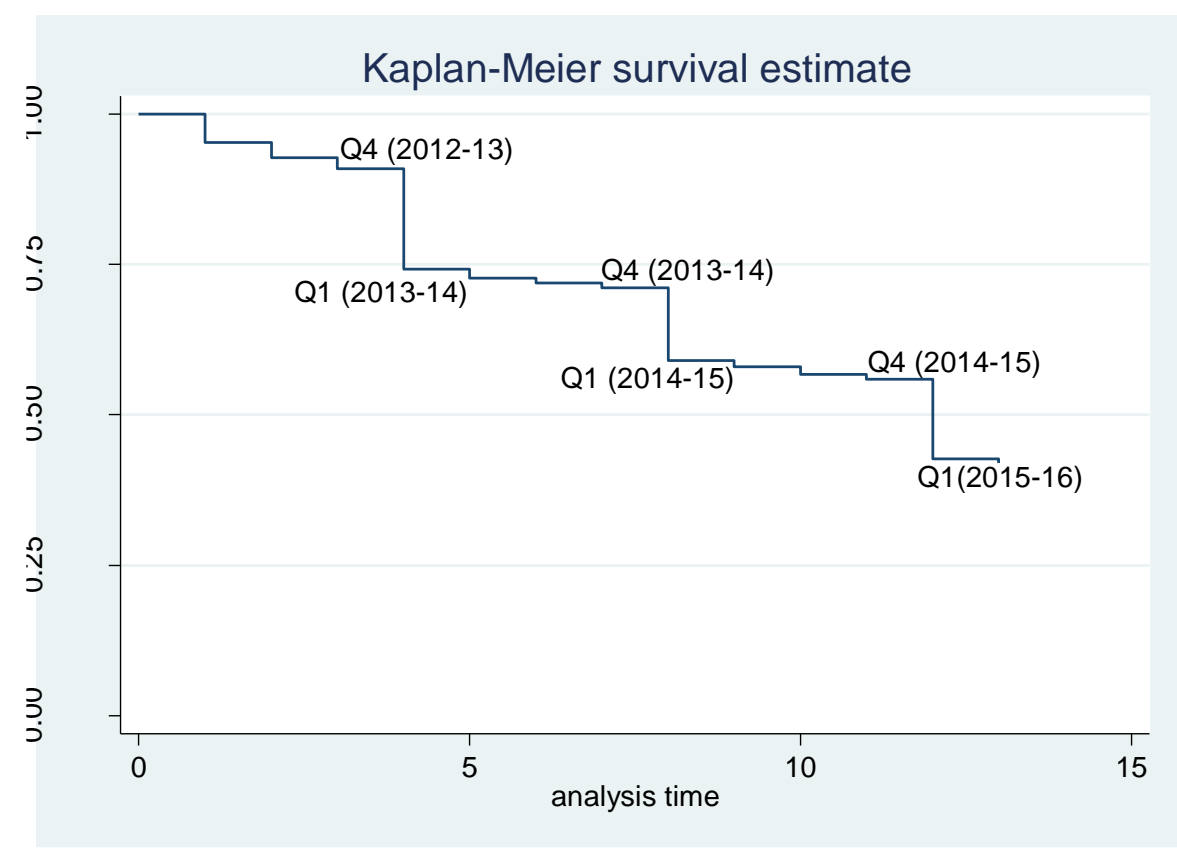

Figure 1. Kaplan-Meier survival probabilities, school year 2012-13 through 2014-15, in fiscal year quarters.

Table 4

\section{Life Table Describing the Count of Students Remaining in their Private School of Choice}

\begin{tabular}{|c|c|c|c|c|c|c|}
\hline Time & $\begin{array}{c}\text { Beginning } \\
\text { Total } \\
\text { (1) }\end{array}$ & $\begin{array}{l}\text { Leaver } \\
(2)\end{array}$ & $\begin{array}{c}\text { Hazard } \\
\text { Ratio } \\
\text { (3) }\end{array}$ & $\begin{array}{c}\text { Survivor } \\
\text { Function } \\
\text { (4) }\end{array}$ & $\begin{array}{l}\text { Switched } \\
\text { to Public } \\
\text { Schools } \\
\text { (5) }\end{array}$ & $\begin{array}{c}\text { Moved to Other Private } \\
\text { Schools without Using } \\
\text { Voucher or Left } \\
\text { Louisiana Entirely } \\
\text { (6) }\end{array}$ \\
\hline \multicolumn{7}{|l|}{ Overall Sample $(N=3,865)$} \\
\hline School Year 2012-13 & 3,861 & 1003 & 0.260 & 0.740 & 860 & 143 \\
\hline School Year 2013-14 & 2,858 & 572 & 0.200 & 0.592 & 463 & 109 \\
\hline School Year 2014-15 & 2,286 & 617 & 0.270 & 0.481 & 453 & 164 \\
\hline \multicolumn{7}{|c|}{$\begin{array}{l}\text { Students in Grades } 3 \text { through } \\
5(2012)(N=1,197)\end{array}$} \\
\hline School Year 2012-13 & 1,196 & 318 & 0.266 & 0.734 & 272 & 46 \\
\hline School Year 2013-14 & 878 & 166 & 0.189 & 0.595 & 133 & 30 \\
\hline School Year 2014-15 & 712 & 185 & 0.260 & 0.449 & 175 & 10 \\
\hline
\end{tabular}

Notes: Counts are based on non-kindergarten students who have ever used LSP vouchers during the 2012-13 to 2014-15 school year, with and without restricting the sample to students in grades 3 through 5 at the baseline school year 2012-13. Usage status is obtained from the applicant file and the school movement status are obtained from SIS 2012-13 through 2015-16. 
There are three important patterns of LSP participants' post-lottery movements. First, a majority of students have changed school section during the years observed. By the end of the third year, $48 \%$ of voucher users remain in the program, resulting in an overall annual attrition rate of about $24 \%$, accounting for $52 \%$ attrition cumulatively over three years. This voucher leaver rate is similar to the MPCP's 22\% to 35\% every year (Rouse, 1998; Cowen et al., 2012; Carlson et al., 2013) and the New York City school choice program's 22\% (Howell, 2004). Second, school switchers are more likely to return to Louisiana public schools than to leave the state public school system entirely. Among voucher users, nearly $74 \%$ of them continued attending the private school of choice through the first year, and about $86 \%$ of voucher leavers, accounting for 860 students, switched back to public schools by the end of school year 2012-13 (Column 5). The public school return rate was $81 \%$ of voucher-program leavers for school year 2013-14 and 73\% of voucher-program leavers for school year 2014-15. Lastly, the hazard and survival trends between the full sample and restricted sample are nearly identical. This result indicates that the restricted sample has the same attrition patterns as the full sample and is representative of the overall sample in terms of program attrition rate, even though it is restricted to students who started in the elementary grades of 3 through 5.

We first use the Cox Proportional Hazards Model to predict LSP leavers by school year: $\hat{h}\left(t_{j}\right)=\exp \left(\right.$ Student $_{i}^{\prime} \cdot \boldsymbol{\beta}+$ Private School $_{i}^{\prime} \cdot \boldsymbol{\gamma}+$ District $_{\boldsymbol{i}}^{\prime} \cdot \boldsymbol{\delta}+$ PublicSchool $_{i}^{\prime} \cdot \boldsymbol{\theta}$

Where voucher using student $i$ 's hazard rate of leaving the LSP private school at year $j$ is estimated as a function of his or her individual characteristics ( Student $_{i}$ ), characteristics of the private school the student was placed in $\left(\right.$ Private $\left._{i}\right)$, residential school district educational resources $\left(\right.$ District $\left._{i}\right)$, and institutional characteristics of their previously attended public school $\left(\right.$ PublicSchool $\left._{i}\right)$. These measures are the same as in Equation 2. To account for spatial 
auto-correlation due to students placed in the same private school having the same private school characteristics and similar community educational resources, robust standard errors are clustered at assigned private school.

More than one event is considered a "failure" of remaining in private schools. A student who used a voucher previously could revert to a Louisiana public school or leave the Louisiana public school system entirely. Therefore, we estimate Competing Risk Regressions, which predict the probability of exiting the LSP voucher program while simultaneously accounting for the probability of leaving the Louisiana public school system entirely (Cowen et al., 2012).

The hazard ratios in both Cox Proportional Hazard Models and Competing-risk Regressions hazard ratios $\beta_{i}$ are not interpreted in the same manner as coefficients in multiple linear regressions. Since the model is in exponential form, a variable with a hazard ratio larger than 1 should be interpreted as having a higher probability of experiencing the hazard of leaving the private school, while a variable with a hazard ratio smaller than 1 should be interpreted as having a lower probability of experiencing that hazard.

\section{Results}

In this section, we present the estimated results on the characteristics that differentiate the voucher applicants from their non-applicant counterparts (Table 5), on characteristics that differentiate the voucher decliners from their voucher-using counterparts (Table 6), and on characteristics differentiating the voucher using students who left LSP private schools from the ones who remained in private schools (Table 7 and Table 8), during the first three years of the expansion of the Louisiana Scholarship Program (school years 2012-13, 2013-14, 2014-15).

Results in Tables 6 through 8 are presented using the full sample and the restricted sample, separately. Moreover, we conduct the estimation using the restricted sample with and 
without controlling for student test scores and associated educational backgrounds, separately. Model 3 in Table 6 and Models 3 through 5 in Table 7 and 8 are our preferred models for interpretation.

\section{Who applies?}

Table 5 presents the estimated marginal effects of the student demographics on LSP application. Results reveal that African American and Hispanic students, as well as students enrolled in the Free/Reduced Price Lunch Program have a significantly higher likelihood of applying for the voucher $(p<.01)$. This pattern indicates that LSP applicants are more disadvantaged than their public school student peers. Students in lower grades show a higher likelihood of applying for the voucher than their higher grade peers $(p<.01)$.

Table 5

Predicting Voucher Applicants

(1)

Baseline Grade Level

Female

Free/Reduced Price Lunch Program

African American

Hispanic

Observations

Significance level $* p<0.10, * * * p<0.01, * * p<0.05$.

Notes: Estimates are average marginal effects after Probit regressions. The dependent variable equals 1 if a student applied for the LSP in 2012.
$-0.001 * * *$

$(0.000)$

0.000

$(0.000)$

$0.007 * * *$

$(0.000)$

$0.014 * * *$

(0.000)

0.003 ***

(0.001)

637,629 


\section{Who declines?}

Table 6 presents the estimated marginal effects of the student individual characteristics and educational backgrounds on the students' decisions to decline vouchers. Our primary results of Model 3, which focuses only on students in grades 3 through 5 at the baseline year, provide little evidence that LSP participating private schools have "cream skimmed" more advantaged students. The Probit model reveals no significant differences between voucher decliners and users in terms of student gender, ethnicity, family background, and baseline test scores. Students with a special educational need tend to have a higher likelihood of declining the voucher $(p<.10)$. These results are consistent across all model specifications.

Students who are more committed to the program tend to be less likely to decline the voucher. In Models 1 and 2, without controlling for student educational backgrounds, students who had participated in the New Orleans Pilot Program are predicted to be about $12 \%$ less likely to decline a voucher when offered. This effect fades out after controlling for student educational backgrounds. Meanwhile, students assigned to their first-choice schools tend to be less likely to decline the assigned private school, consistent across all model specifications $(p<.05)$.

The awarded private schools' attributes tend to play a more important role than student characteristics in voucher usage decision making. All else being equal, students who were lottery-placed in private schools with lower tuition rates are more likely to decline the voucher: a $\$ 1,000$ increase in school tuition is associated with a 2 -to-5 percentage points reduction in the likelihood of declining a voucher, all else being equal, significant at $p<.01$. As school tuition rates tend to be positively correlated with school quality, it is unsurprising that families awarded voucher placements in higher quality private schools are more likely to use them at the assigned schools. Another significant private school predictor of declining is the distance between the 
awarded private school and a student's home, as a one-mile increase in the home-to-school distance is associated with a 0.5 percentage point increase in the likelihood of declining the voucher, all else being equal, significant at the .05 level. This result is reasonable given the burden of long school commutes. Furthermore, students assigned to private schools with higher proportions of minority students are more likely to decline the voucher, at the .01 level of significance. These preference patterns are consistent across all model specifications for the restricted and full LSP samples.

Notably, students with better educational alternatives have a higher tendency to decline the awarded voucher. Controlling for other factors, students living in school districts with higher educational expenditures and more charter schools are more likely to decline their LSP placements, significant at the .01 and .05 level, respectively.

Lastly, students who have attended charter schools have a higher tendency to decline the voucher, while students who attended magnet schools in 2011-12 have a lower tendency to decline. Students enrolled in charter schools in the baseline year 2011-12 on average are 9.6 percentage points more likely to decline awarded vouchers, compared to their peers from TPSs $(p<.05)$. Students enrolled in magnet schools in 2011-12 are 11 percentage points less likely to decline awarded vouchers, compared to their peers from TPSs $(p<.05)$. These results could be due to the families of children who have attended public charter schools being more comfortable staying in public schools while the families of children who have attended public magnet schools and TPSs are more willing to make the jump to unfamiliar private school environments. 
Table 6

Predicting Voucher Decliners

\begin{tabular}{|c|c|c|c|c|c|c|}
\hline \multirow{4}{*}{ Student Characteristics } & \multirow{2}{*}{\multicolumn{2}{|c|}{$\begin{array}{c}\text { Overall Sample } \\
\text { Model (1) }\end{array}$}} & \multicolumn{4}{|c|}{ Students in Grades 3 through 5 (2012) } \\
\hline & & & \multicolumn{2}{|c|}{ Model (2) } & \multicolumn{2}{|c|}{ Model (3) } \\
\hline & & & & & & \\
\hline & -0.014 & $(0.013)$ & -0.013 & $(0.019)$ & -0.036 & $(0.031)$ \\
\hline African American & 0.026 & $(0.025)$ & -0.008 & $(0.034)$ & 0.011 & $(0.047)$ \\
\hline Hispanic & -0.080 & $(0.056)$ & & & & \\
\hline Special Education Need & $0.043 * *$ & $(0.021)$ & $0.058^{*}$ & $(0.032)$ & $0.083^{*}$ & $(0.046)$ \\
\hline Baseline Grade Level & 0.004 & $(0.003)$ & -0.011 & $(0.013)$ & -0.010 & $(0.019)$ \\
\hline Multiple Birth Siblings & 0.011 & $(0.036)$ & 0.106 & $(0.077)$ & 0.069 & $(0.096)$ \\
\hline Neighborhood Mean Household Income $(\$ 1,000)$ & 0.000 & $(0.000)$ & 0.000 & $(0.000)$ & 0.001 & $(0.001)$ \\
\hline NOLA Participant & $-0.124 * * *$ & $(0.030)$ & $-0.129 * * *$ & $(0.039)$ & -0.059 & $(0.152)$ \\
\hline Awarded LSP to 1st Choice School & $-0.101 * * *$ & $(0.020)$ & $-0.065 * *$ & $(0.035)$ & $-0.122 * * *$ & $(0.044)$ \\
\hline Baseline Achievement Score & & & & & 0.009 & $(0.020)$ \\
\hline \multicolumn{7}{|l|}{ Awarded Private School } \\
\hline Count of Voucher Students & 0.000 & $(0.000)$ & 0.000 & $(0.000)$ & 0.000 & $(0.000)$ \\
\hline Private School Minority Enrollment (\%) & $0.001 * * *$ & $(0.000)$ & $0.001 * * *$ & $(0.000)$ & $0.001 * *$ & $(0.001)$ \\
\hline Tuition Rate $(\$ 1,000)$ & -0.013 & $(0.009)$ & $-0.022 * * *$ & $(0.007)$ & $-0.045 * * *$ & $(0.012)$ \\
\hline Distance to Home (mile) & $0.004 * * *$ & $(0.001)$ & $0.005 * * *$ & $(0.001)$ & $0.006 * *$ & $(0.002)$ \\
\hline \multicolumn{7}{|l|}{ Community Educational Resources } \\
\hline Per-pupil Expenditure $(\$ 1,000)$ & & & & & $0.011 * *$ & $(0.005)$ \\
\hline Count of Charter School & & & & & $0.020 * * *$ & $(0.007)$ \\
\hline District Minority Enrollment (\%) & & & & & -0.001 & $(0.001)$ \\
\hline \multicolumn{7}{|l|}{ Previously Attended Public School } \\
\hline Charter School & & & & & $0.096 * *$ & $(0.051)$ \\
\hline Magnet School & & & & & $-0.106 * *$ & $(0.048)$ \\
\hline Observations & 3585 & & 1116 & & 581 & \\
\hline
\end{tabular}

Significance level $* p<0.10, * * * p<0.01, * * p<0.05$.

Notes: Estimates are average marginal effects after Probit regressions. The dependent variable equals 1 if a student has ever declined a voucher after initially being offered one. Model 1 presents estimates using the full sample and Models 2 and 3 are estimations for the restricted sample. Hispanic is omitted in Models 2 and 3 due to low numbers of students in that ethnicity category. Robust standard errors appear in parentheses and are clustered at the lottery-assigned private schools. 
With the important exception of a disability, student characteristics, including baseline test scores, are not predictive of declining an LSP voucher placement. Families more committed to the LSP due to prior experience in the Pilot program tend to be less likely to decline the voucher. Additionally, students assigned to private schools with lower tuition costs (lower quality), students who have better alternatives, and students who previously attended charter schools, are all more likely to decline the LSP when offered. Voucher decliners are not likely to be more disadvantaged, either educationally or economically, than their voucher user counterparts, except regarding having a disability. These results are less consistent with a hypothesis that private schools are "cream skimming" certain students into the program as they are with the claim that students are voluntarily deciding whether or not to participate in the LSP based on their commitment to this program and their educational alternatives.

\section{Who left LSP private schools?}

Previous research suggests that students who feel socially alienated and families who cannot manage the logistics and demands of a private school education may opt out from attending voucher-participating private schools (Stewart \& Wolf, 2014; Howell, 2004). These students are more likely to come from disadvantaged families.

To test if schools tend to push certain students out of the program, we model the relationship among students, residential school districts, and the attending private schools, all while accounting for the passage of time, using a Cox Hazards Model. We condition the voucher usage every year on the same student, family, and school characteristics discussed previously. 
Table 7 reports estimates of Equation 7, where each reported coefficient is the associated hazard ratio for each factor of leaving the LSP program. Like odds ratios in logit regressions, hazard ratios should be interpreted as exponentiated coefficients: coefficients greater than 1 indicate increases in the likelihood of a student leaving the voucher program, while coefficients less than 1 indicate decreases in the likelihood of a student leaving the program. ${ }^{7}$

We first provide the estimated effects of student demographics and the characteristics of the private school attended on the hazard of leaving the LSP, based on the full sample (Model 1) and the restricted sample (Model 2). We then include student educational background factors along with test scores in three specifications based on the restricted sample: with baseline math test score Test $t_{t}$ only (Model 3), math test score the year the student might leave Test $($ Model 4), and math test gain score from the previous year to the year the student might leave Test $_{t}-$ Test $_{t-1}$ (Model 5).

Several important trends are clear. First, student test scores influence the decision regarding whether or not to leave the private school a student is attending through the LSP. Students with lower baseline test scores show a higher probability of leaving the LSP private school after accounting for their demographics and educational backgrounds. This finding aligns with previous studies (Rouse, 1998; Cowen et al., 2012; Carlson et al., 2013; Figlio et al., 2014). The effects of the most recent student achievement score and gain score on student leaving decisions each year are not significantly different from zero after controlling for student demographics and baseline achievement. That is, there is little evidence that the LSP is pushing out students with lower academic performance experienced while in their chosen private schools.

\footnotetext{
${ }^{7}$ Hazard ratios always are positive numbers.
} 
Second, only a couple of student demographics show consistent effects on the hazard of leaving the LSP private school. Male and higher-grade voucher-using students are more likely to leave, significant at the .10 and .01 level, respectively, for both the full LSP sample and the restricted sample. Students with a disability tend to leave the private school at a higher rate, yet this effect is only significant for the overall sample $(p<.10)$ which includes a larger group of students with special needs than the restricted sample. The effects of gender, disability status, and grade level on leaving behavior are consistent with previous studies (Carlson et al., 2013; Howell, 2004; Rouse, 1998).

Pilot program participants tend to face a lower risk of returning to public schools. The hazard ratio for having previously participated in the New Orleans Pilot Program is smaller than 1 across all model specifications, and is statistically significant when only accounting for student background factors and the characteristics of assigned private schools, indicating those students tend to have significantly lower tendencies of leaving the private schools they are attending through the program. After including student test scores and educational backgrounds, students who were awarded their first-choice schools face a significantly greater risk of leaving the private school of choice $(p<.01)$, which is contrary to our expectation.

Characteristics of voucher-assigned private schools show a more consistent and significant effect on the hazards of leaving the LSP than do most student characteristics. When accounting for only student demographics, students in private schools with higher tuition tend to have a lower likelihood of leaving the LSP, significant at the .10 level, for both the full and restricted samples. This potential school quality effect fades out after controlling for student test scores and other educational background factors. Students who attend LSP private schools with 
higher proportions of minority students and who face longer school commutes have a greater risk of leaving the LSP. These patterns hold across all model specifications.

Finally, the effects of students' residential community educational resources and whether or not they previously attended a public school are not significantly associated with the hazard of leaving the LSP, all else being equal, with the exception that a higher residential district's perpupil educational expenditure predicts a higher likelihood of leaving the LSP after initial enrollment.

In sum, males, students in higher grades, and students who did not attend the Pilot program face greater risks of exiting the private school that they are attending through the LSP. There is no consistent evidence that the LSP is "pushing out" demographically more disadvantaged students. Meanwhile, accounting for student demographics, voucher-using students with lower baseline achievement, those in private schools with a higher proportion of minority students and farther from home all tend to be more likely to leave the LSP. Students residing in districts with a higher educational per-pupil expenditure tend to leave the LSP at a higher rate, perhaps attracted by the greater resources in the public schools. 
Table 7

Predicting Leaving the LSP, Cox Proportional Hazards Model

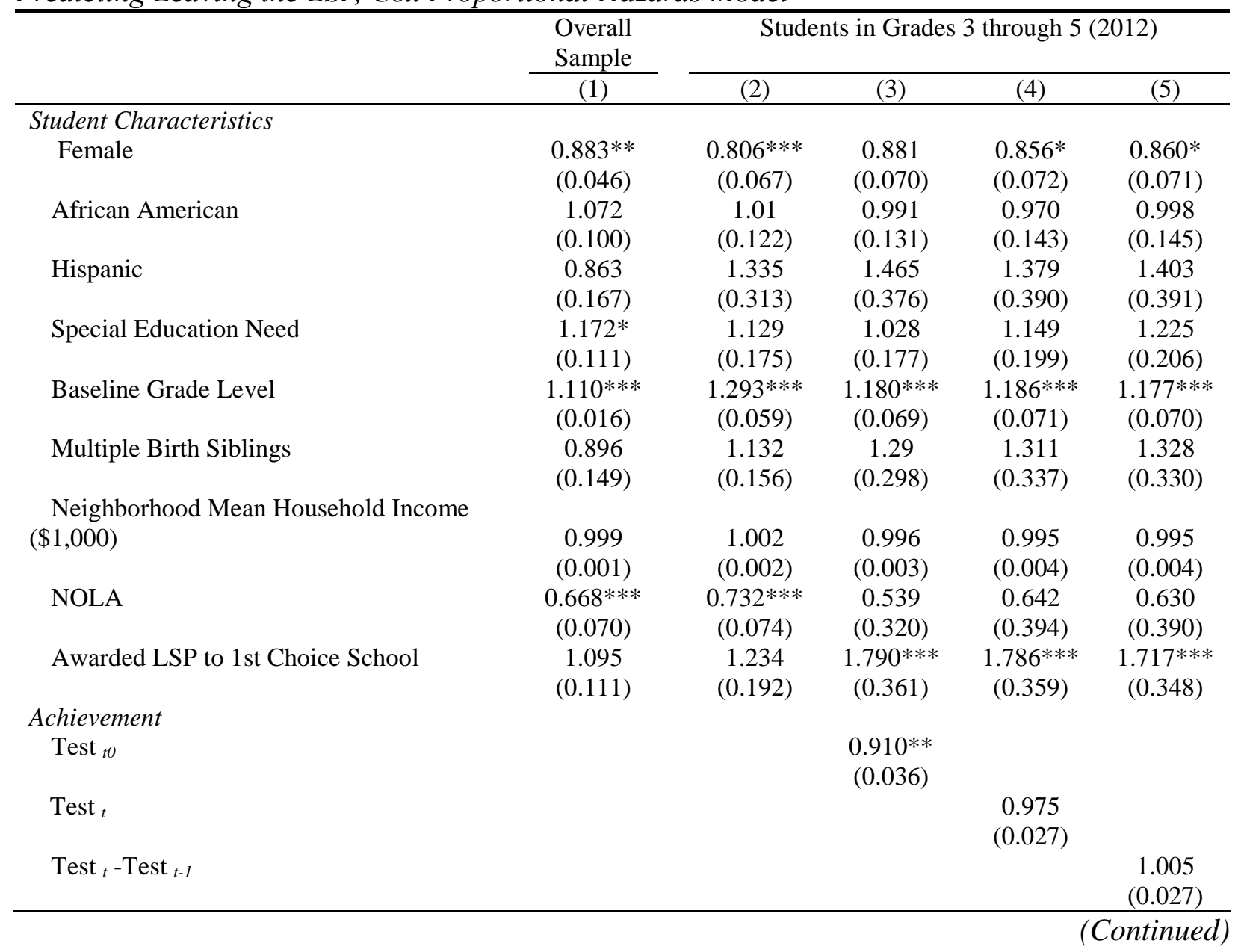


Table 7 (continued)

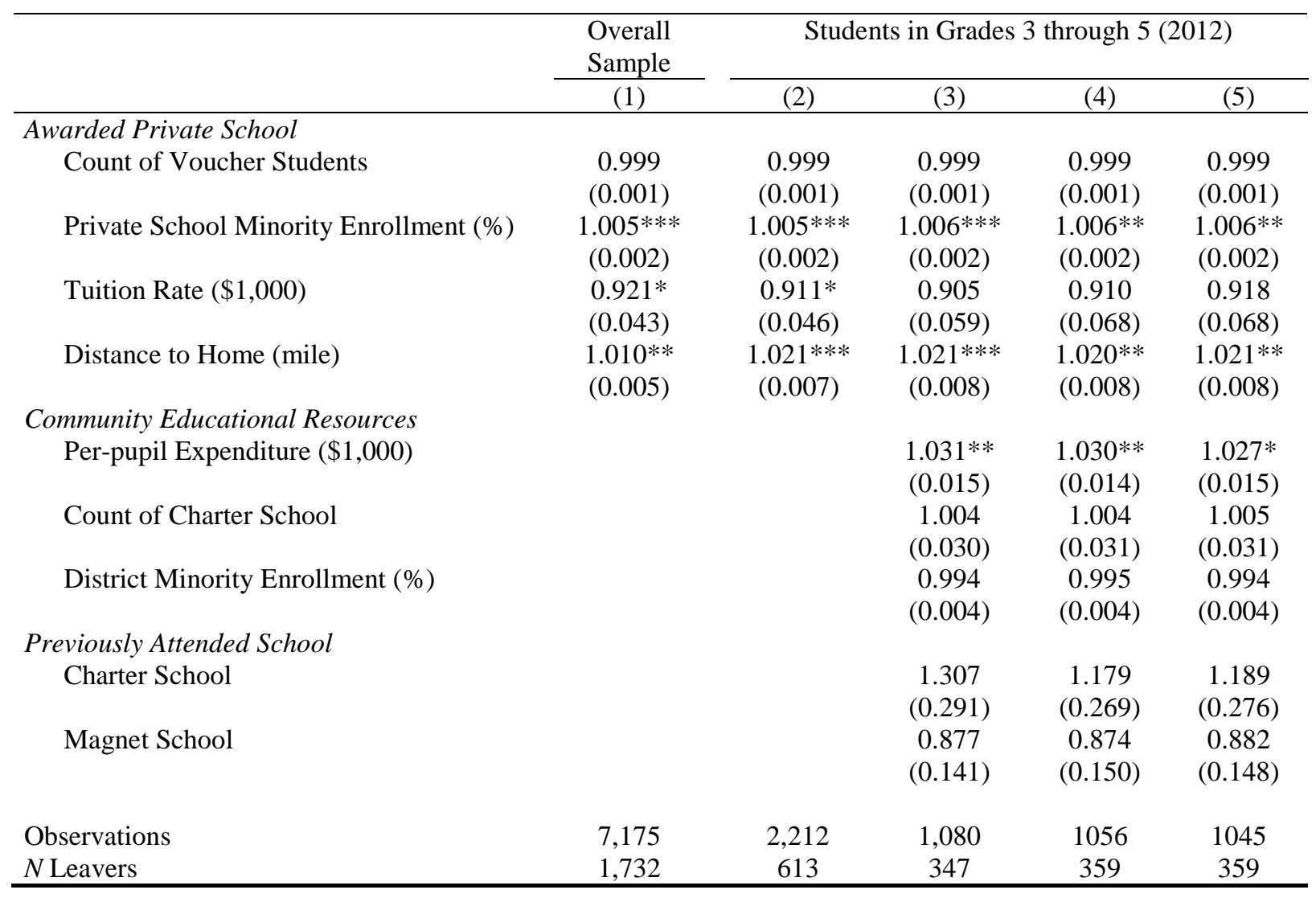

Significance level $* p<.10 . * * p<.05 . * * * p<.01$.

Notes: Cox Proportional Hazard Models are performed, defining the hazard as 1 if a student left the LSP at year $t$. Model 1 presents estimates using the full sample while Models 2 through 5 are estimations for the restricted sample. Estimates are hazard ratios. Robust standard errors appear in parentheses and are clustered at the lottery-assigned private school.

\section{Who returned to public schools?}

The leavers comprise two groups of students: those who stopped using the voucher to attend LSP private schools because they chose to return to the public school system, and those who left the program because they had to, for both structural reasons (e.g. graduated) and nonstructural reasons (e.g. moved out of state) and no longer trackable in the Student Information System. Since those two groups of leavers are based on a different logic, we further conduct a robustness check of factors predicting LSP students returning to public schools using Competing-risk Regressions. In these estimations, each reported coefficient is the associated 
hazard ratio of switching to public schools for each factor, with the competing possibility of switching to another private school without using the voucher or leaving the state.

Table 8 presents the estimations from Competing-risk Regressions. As is the case for LSP leavers generally, recent math achievement and achievement gains are not predictive of students returning to public schools in school years 2012-13 through 2014-15. Student demographics perform similar roles as they do in predicting LSP leavers, as males and higher-grade voucherusing students face higher risks of switching to public schools for the full sample $(p<.05)$, yet these effects fade out in the restricted sample. African American and Hispanic students tend to face a higher risk of switching to public schools in the full LSP sample; however, the result is only statistically significant in some of the model specifications. As was the case in predicting LSP leavers, students who attended the Pilot program tend to have a significantly lower likelihood of switching to public schools $(p<.01)$, significant only when controlling for student demographics and characteristics of attending private schools. Still, students who were awarded their first-choice schools tend to leave them at a higher rate $(p<.01)$.

Characteristics of voucher-assigned private schools show a consistent and significant effect on the hazards of returning to public schools. Students in private schools with higher proportions of minority students and schools located farther from home are at greater risk of switching to public schools. These patterns hold across all model specifications. 
Table 8

Predicting Switching to Public Schools, Competing Hazard Model

\begin{tabular}{|c|c|c|c|c|c|}
\hline & \multirow{2}{*}{$\begin{array}{c}\text { Overall } \\
\text { Sample } \\
(1)\end{array}$} & \multicolumn{4}{|c|}{ Students in Grades 3 through 5 (2012) } \\
\hline & & $(2)$ & (3) & (4) & $(5)$ \\
\hline \multicolumn{6}{|l|}{ Student Characteristics } \\
\hline \multirow[t]{2}{*}{ Female } & $0.851 * * *$ & $0.820 * *$ & 0.891 & $0.839 *$ & 0.854 \\
\hline & $(0.039)$ & $(0.065)$ & $(0.085)$ & $(0.084)$ & $(0.086)$ \\
\hline \multirow[t]{2}{*}{ African American } & $1.322 * *$ & 1.280 & 1.315 & 1.361 & 1.346 \\
\hline & $(0.165)$ & $(0.204)$ & $(0.261)$ & $(0.284)$ & $(0.274)$ \\
\hline \multirow[t]{2}{*}{ Hispanic } & 0.920 & $1.652 *$ & 1.658 & $1.843^{*}$ & $1.821^{*}$ \\
\hline & $(0.217)$ & $(0.479)$ & $(0.546)$ & $(0.599)$ & $(0.580)$ \\
\hline \multirow[t]{2}{*}{ Special Education Need } & 1.041 & 1.048 & 0.889 & 0.982 & 1.025 \\
\hline & $(0.129)$ & $(0.218)$ & $(0.205)$ & $(0.228)$ & $(0.237)$ \\
\hline \multirow[t]{2}{*}{ Baseline Grade Level } & $1.058 * * *$ & $1.222 * * *$ & $1.131 *$ & $1.125^{*}$ & $1.120^{*}$ \\
\hline & $(0.021)$ & $(0.060)$ & $(0.072)$ & $(0.070)$ & $(0.071)$ \\
\hline \multirow[t]{2}{*}{ Multiple Birth Siblings } & 0.955 & 1.071 & 1.243 & 1.256 & 1.228 \\
\hline & $(0.172)$ & $(0.278)$ & $(0.356)$ & $(0.382)$ & $(0.378)$ \\
\hline \multirow{2}{*}{$\begin{array}{l}\text { Neighborhood Mean Household Income } \\
(\$ 1,000)\end{array}$} & 0.999 & 1.000 & $0.993 * *$ & $0.992 * *$ & $0.992 * *$ \\
\hline & $(0.001)$ & $(0.002)$ & $(0.003)$ & $(0.004)$ & $(0.004)$ \\
\hline \multirow[t]{2}{*}{ NOLA } & $0.601 * * *$ & $0.623 * * *$ & 0.638 & 0.731 & 0.697 \\
\hline & $(0.064)$ & $(0.075)$ & $(0.403)$ & $(0.488)$ & $(0.465)$ \\
\hline \multirow[t]{2}{*}{ Awarded LSP to 1st Choice School } & 1.093 & $1.539 * *$ & $2.113 * * *$ & $2.183^{* * *}$ & $2.108 * * *$ \\
\hline & $(0.120)$ & $(0.299)$ & $(0.549)$ & $(0.539)$ & $(0.542)$ \\
\hline \multicolumn{6}{|l|}{ Achievement } \\
\hline \multirow[t]{2}{*}{ Test ${ }_{t 0}$} & & & 0.912 & & \\
\hline & & & $(0.052)$ & & \\
\hline \multirow[t]{2}{*}{ Test $_{t}$} & & & & 0.965 & \\
\hline & & & & $(0.064)$ & \\
\hline \multirow[t]{2}{*}{ Test $_{t}$-Test ${ }_{t-1}$} & & & & & 1.086 \\
\hline & & & & & $(0.069)$ \\
\hline
\end{tabular}


Table 8 (continued)

\begin{tabular}{|c|c|c|c|c|c|}
\hline & \multirow{2}{*}{$\begin{array}{c}\begin{array}{c}\text { Overall } \\
\text { Sample }\end{array} \\
(1)\end{array}$} & \multicolumn{4}{|c|}{ Students in Grade 3 through 5 (2012) } \\
\hline & & (2) & (3) & (4) & (5) \\
\hline \multicolumn{6}{|l|}{ Awarded Private School } \\
\hline Count of Voucher Students & $\begin{array}{c}0.999 \\
(0.001)\end{array}$ & $\begin{array}{c}0.999 \\
(0.001)\end{array}$ & $\begin{array}{c}0.999 \\
(0.001)\end{array}$ & $\begin{array}{c}0.999 \\
(0.001)\end{array}$ & $\begin{array}{c}0.999 \\
(0.001)\end{array}$ \\
\hline Private School Minority Enrollment (\%) & $\begin{array}{l}1.003 * \\
(0.002)\end{array}$ & $\begin{array}{l}1.004 * * \\
(0.002)\end{array}$ & $\begin{array}{l}1.005^{* *} \\
(0.002)\end{array}$ & $\begin{array}{l}1.005^{* *} \\
(0.003)\end{array}$ & $\begin{array}{l}1.005^{* *} \\
(0.003)\end{array}$ \\
\hline Tuition Rate $(\$ 1,000)$ & $\begin{array}{c}0.959 \\
(0.036)\end{array}$ & $\begin{array}{c}0.968 \\
(0.026)\end{array}$ & $\begin{array}{c}0.976 \\
(0.047)\end{array}$ & $\begin{array}{c}0.990 \\
(0.049)\end{array}$ & $\begin{array}{c}0.991 \\
(0.050)\end{array}$ \\
\hline Distance to Home (mile) & $\begin{array}{c}1.003 \\
(0.007)\end{array}$ & $\begin{array}{c}1.021 * * * \\
(0.007)\end{array}$ & $\begin{array}{c}1.021^{* *} \\
(0.010)\end{array}$ & $\begin{array}{l}1.022 * * \\
(0.009)\end{array}$ & $\begin{array}{l}1.022 * * \\
(0.009)\end{array}$ \\
\hline \multicolumn{6}{|l|}{ Community Educational Resources } \\
\hline Per-pupil Expenditure $(\$ 1,000)$ & & & $\begin{array}{c}1.012 \\
(0.021)\end{array}$ & $\begin{array}{c}1.008 \\
(0.023)\end{array}$ & $\begin{array}{c}1.016 \\
(0.026)\end{array}$ \\
\hline Count of Charter School & & & $\begin{array}{c}1.020 \\
(0.034)\end{array}$ & $\begin{array}{c}1.020 \\
(0.035)\end{array}$ & $\begin{array}{c}1.025 \\
(0.035)\end{array}$ \\
\hline District Minority Enrollment (\%) & & & $\begin{array}{c}0.994 \\
(0.004)\end{array}$ & $\begin{array}{c}0.994 \\
(0.004)\end{array}$ & $\begin{array}{l}0.992 * \\
(0.004)\end{array}$ \\
\hline \multicolumn{6}{|l|}{ Previously Attended School } \\
\hline Charter School & & & $\begin{array}{c}1.084 \\
(0.233)\end{array}$ & $\begin{array}{c}1.047 \\
(0.256)\end{array}$ & $\begin{array}{c}1.081 \\
(0.271)\end{array}$ \\
\hline Magnet School & & & $\begin{array}{c}0.952 \\
(0.187)\end{array}$ & $\begin{array}{c}0.955 \\
(0.196)\end{array}$ & $\begin{array}{c}0.967 \\
(0.199)\end{array}$ \\
\hline Observations & 7,179 & 2,213 & 1,081 & 1,057 & 1,045 \\
\hline$N$ Leavers & 1,378 & 481 & 288 & 276 & 273 \\
\hline
\end{tabular}

Significance level $* p<.10 . * * p<.05 . * * * p<.01$.

Notes: Competing-risk Hazards Models are performed, defining failure as 1 if a student left the LSP private school at year $t$ and state competing as 1 if a student is untraceable at the current year. Model 1 presents estimates using the full sample, Models 2 through 5 are estimations for the restricted sample. Estimates are hazard ratios. Robust standard errors appear in parentheses and are clustered at the lottery assigned private school.

\section{Who stays?}

Given that the LSP applicants were negatively self-selected but the voucher users were positively selected, we pose the last question: in the end, how are the persistent LSP users different from their non-applicant peers demographically?

Table 9 presents the demographic comparisons between the LSP non-applicants and the year 3 users who were in a public school prior to applying to the program. T-test results reveal that even the persistent users were negatively self-selected, meaning that they are more disadvantaged than their non-applicant peers. Year 3 LSP voucher users are 25 percentage points 
more likely to receive Free/Reduced Price Lunch and 35 percentage points more likely to be African American compared to the non-applicants. Year 3 voucher users also are more likely to be female than are their non-applicant peers.

Table 9

Student Demographic Differences between Non-Applicants and Year 3 Users

\begin{tabular}{lllrl}
\hline & $\begin{array}{l}\text { Year 3 Users Mean } \\
(\mathrm{N}=955)\end{array}$ & $\begin{array}{l}\text { Non-Applicants Mean } \\
(\mathrm{N}=695,812)\end{array}$ & Diff & \\
\hline Grade Level (2012) & 3.541 & 6.226 & -2.686 & $* * *$ \\
Female & 0.532 & 0.487 & 0.045 & $* * *$ \\
Free/Reduced Price Lunch Program & 0.917 & 0.668 & 0.249 & $* * *$ \\
African American & 0.798 & 0.448 & 0.350 & $* * *$ \\
Hispanic & 0.040 & 0.041 & -0.001 & \\
White & 0.147 & 0.476 & -0.329 & $* * *$ \\
\hline Significance level $* p<.10 . * * p<.05 . * * * p<.01$ two tail t-test. & & &
\end{tabular}

\section{Discussion and Conclusions}

This study investigates the participation patterns in the Louisiana Scholarship Program during the first three years after the program expanded statewide (school years 2012-13, 201314, and 2014-15). The LSP is one of the nation's first statewide voucher programs for lowincome students and is based on lottery placement while accounting for an applicant's portfolio of preferred private schools. The data we use in this study to examine application include all K12 public school students in Louisiana and all eligible applicants to the LSP. The data we use to examine patterns of voucher use include all LSP non-kindergarten awardees. The comprehensiveness of our data gives the study high external validity at the state level. However, student enrollment status at the end of school year 2014-15 is not available, so our analysis predicting public school returnees is restricted to the 2012-13 and 2013-14 school years. Further, we do not have a direct measure of family income or family social-economic status. The measure Neighborhood Mean Household Income can only offer indirect information about variation in 
family financial resources, and its effects are not consistently predictive of student movement among schools.

A simple description confirms that the LSP successfully reached its targeted population of students. We find a comparatively high take-up rate $(87.3 \%)$ and a relatively low attrition rate ( $24 \%$ regarding the original sample annually) during the first three years among the nonkindergarten students who were offered voucher placements. This high take-up and continuation rate indicates a higher parental satisfaction for the assigned schools, even though their children experienced smaller test-score gains than their peers who lost the placement lotteries (Mills \& Wolf, 2019; Mills \& Wolf, 2017).

Little evidence of school "cream skimming" of high-achieving students was found. Table 10 summarizes the effect of student characteristics in predicting LSP application, initial declining, and leaving later on (including students who left the program in general and returned to the public school system). We find that the LSP attracted a more disadvantaged student population to apply. We see little evidence of school "cream skimming" based on student demographics, as gender, ethnicity, and grade level are not predictive of initial voucher declining. Students with disabilities, however, have a higher tendency of declining a voucher. Our data do not allow us to determine if students with disabilities were discouraged from enrolling in an LSP school by school personnel or if those particular students simply viewed private school environments and offerings as less attractive for them compared to what is available for students with disabilities in public schools. There is some evidence that males and higher-grade students leave the LSP and return to the public sector at higher rates than females and lower-grade students do. 
Table 10

Summary of Effects of Student Characteristics in Predicting LSP Participation

Initial Application Initial Declining

(vs. non-applicants) (vs. ever users)

Leaving
(vs. persisting)

Returning to

Public School

Year 3 Users

vs. persisting

Student Characteristics

Free/Reduced Price Lunch Program

$N / A$
$*$

$N / A$

African American

Hispanic

Special Education Need

Baseline Grade Level

Multiple Birth Siblings

\begin{tabular}{|c|c|c|c|c|}
\hline$+* * *$ & $N / A$ & $\begin{array}{r}N / A \\
-*\end{array}$ & N/A & $\begin{array}{l}+* * * \\
+* * *\end{array}$ \\
\hline$+* * *$ & & & & $+* * *$ \\
\hline$+* * *$ & & & $+*$ & \\
\hline N/A & $+*$ & & & $N / A$ \\
\hline - *** & & $+* * *$ & $+*$ & - *** \\
\hline$N / A$ & & & & $N / A$ \\
\hline$N / A$ & & & $-* *$ & $N / A$ \\
\hline$N / A$ & - $* * *$ & & & $N / A$ \\
\hline$N / A$ & & $+* * *$ & $+*$ & $N / A$ \\
\hline$N / A$ & & $-* *$ & & $N / A$ \\
\hline$N / A$ & & & & N/A \\
\hline$N / A$ & $+* *$ & $+* *$ & $+* *$ & $N / A$ \\
\hline$N / A$ & - $* * *$ & & & $N / A$ \\
\hline$N / A$ & $+* *$ & $+* *$ & $+* *$ & N/A \\
\hline$N / A$ & $+* *$ & $+* *$ & & N/A \\
\hline$N / A$ & $+* * *$ & & & $N / A$ \\
\hline$N / A$ & & & $-*$ & N/A \\
\hline$N / A$ & $+* *$ & & & $N / A$ \\
\hline N/A & $-* *$ & & & $N / A$ \\
\hline
\end{tabular}

Neighborhood Mean Household Income $(\$ 1,000)$

NOLA Participant

Awarded LSP to 1st Choice School

Baseline Achievement Score

Awarded Private School

Count of Voucher Students

Private School Minority Enrollment (\%)

Tuition Rate $(\$ 1,000)$

Distance to Home (mile)

Community Educational Resources

Per-pupil Expenditure $(\$ 1,000)$

Count of Charter School

District Minority Enrollment (\%)

$N / A$

$-* *$

Significance level $* p<0.10, * * * p<0.01, * * p<0.05$. 
Student test scores do not predict initial voucher usage. Lower achieving students at the baseline year tend to leave the program at a higher rate in later years; however, this pattern is not significantly predictive for those who switched back to public schools. Other measures of student achievement while at LSP private schools, including student achievement scores and gain scores, are not predictive of LSP attrition. These patterns should allay concerns of selection bias in interpreting the LSP's Treatment-On-Treated effects on student test scores in the longitudinal evaluation (Mills \& Wolf, 2019; Mills \& Wolf, 2017b; Mills and Wolf, 2017a; Mills \& Wolf, 2016; Mills, 2015). The lottery winners who opted out of the LSP by either declining the offered voucher or by leaving the program later on are, on average, not lower achieving students than the program stayers.

Families with higher commitment to the program, as measured by having previously attended the New Orleans Pilot Program, show higher tendencies of both using the voucher and remaining in LSP private schools (full sample only). LSP applicants who were awarded the voucher for first-choice schools are more likely to use the voucher initially but tend to leave the program and return to the public sector in later years at a higher rate.

Students assigned to private schools with a larger proportion of minority students, and with farther distances between home and school, tend to be more likely to decline the voucher and to leave the LSP and switch to public schools later on. Meanwhile, students residing in better educationally funded districts with more schooling alternatives have a higher tendency of both declining the voucher and leaving the LSP after initially attending LSP private schools. These results are all consistent with families carefully evaluating their specific school choices. 
At the end, even students who persisted through three years of LSP voucher use tend to be negatively self-selected. Year 3 LSP users are more disadvantaged, demographically, than their public school student peers.

This study contributes to the existing literature on student participation patterns in publicly funded voucher programs. Previous studies of those patterns in the Milwaukee Parental Choice and the New York City school choice programs show that disadvantaged students were disproportionately attracted to the programs but also were more likely to refuse to use the voucher when offered and to exit voucher programs early after initially using one. The higher tendency to reject a voucher or quit school choice programs for those students indicates they were struggling in their private school. Our study reveals, however, this pattern is not the case in the LSP: The applicants to the LSP were more disadvantaged demographically than the nonapplicants, yet students who declined to use a voucher and students who exited the program are not necessarily the most disadvantaged groups of students based on a variety of social, economic, and educational measures. There is little evidence that private schools participating in the LSP are "cream skimming" advantaged students based on their characteristics, with the important exception of students with disabilities, whom small private schools may not be able to attract, especially with the meager resources of a $\$ 5,000$ per year LSP voucher.

There is also no substantial evidence that private schools participating in the LSP "push out" disadvantaged students based on their characteristics and test score performance once enrolled. On the contrary, students tend to self-select themselves out of the program when they attend private schools with a greater share of minority enrollments, tend to have longer distances to travel from school to home, and tend to have better residential district educational resources. Since those factors also contribute to attrition rates in private schools regardless of voucher 
programs, we cannot confirm if the attrition pattern is specifically due to the LSP or generally part of the nature of private schooling. 


\section{References}

Abdulkadiroğlu, A., Pathak, P. A., \& Roth, A. E. (2005). The New York City high school match. American Economic Review, 95(2), 364-367.

Abdulkadiroğlu, A., Pathak, P. A., Roth, A. E., \& Sönmez, T. (2005). The Boston public school match. American Economic Review, 95(2), 368-371.

Altonji, J. G., Huang, C. I., \& Taber, C. R. (2015). Estimating the cream skimming effect of school choice. Journal of Political Economy, 123(2), 266-324.

Boruch, R., Moya, D., \& Snyder, B. (2002). The importance of randomized field trials in education and related areas. In F. Mosteller \& R. Boruch (Eds.), Evidence matters: Randomized trials in education research (pp. 50-79). Washington, DC: Brookings.

Campbell, D. E., West, M. R., \& Peterson, P. E. (2005). Participation in a national, means-tested school voucher program. Journal of Policy Analysis and management, 24(3), 523-541.

Carlson, D., Cowen, J. M., \& Fleming, D. J. (2013). Life after vouchers: What happens to Students Who Leave Private Schools for the Traditional Public Sector? Educational Evaluation and Policy Analysis, 35(2), 179-199.

Cowen, J. M. (2008). School choice as a latent variable: Estimating the "complier average causal effect" of vouchers in Charlotte. Policy Studies Journal, 36(2), 301-315.

Cowen, J. M. (2010). Who chooses, who refuses? Learning more from students who decline private school vouchers. American Journal of Education, 117(1), 1-24.

Cowen, J. M., Fleming, D. J., Witte, J. F., \& Wolf, P. J. (2012). Going public: Who leaves a large, longstanding, and widely available urban voucher program? American Educational Research Journal, 49(2), 231-256.

Cox, D., Reid, N. (1984). Analysis of Survival Data. New York: Chapman and Hall

Chubb, J. E., \& Moe, T. M. (1990). America's public schools: Choice is a panacea. The Brookings Review, 8(3), 4-12.

DeAngelis, C. A., \& Erickson, H. H. (2018). What leads to successful school choice programs: A review of the theories and evidence. Cato Journal, 38, 247.

Figlio, D. N. (2014). Evaluation of the Florida Tax Credit Scholarship Program participation, compliance and test scores in 2012-13. National Bureau of Economic Research, August. Website link: https://www.floridaschoolchoice.org/pdf/FTC_Research_201213 report.pdf.

Figlio, D. N., Hart, C. M. D., \& Metzger, M. (2010). Who uses a means-tested scholarship, and what do they choose?. Economics of Education Review,29(2), 301-317. 
Figlio, D. N., \& Karbownik, K. (2016). Evaluation of Ohio's EdChoice Scholarship Program. Thomas B. Fordham Institute, July.

Fleming, D. J., Cowen, J. M., Witte, J. F., \& Wolf, P. J. (2015). Similar students, different choices: Who uses a school voucher in an otherwise similar population of students? Education and Urban Society, 47(7), 785-812.

Friedman, Milton (1955), "The role of government in education," in Robert A. Solo (ed.), Economics and the Public Interest. New Brunswick, NJ: Rutgers University Press.

Friedman, Milton (1962), "The role of government in education," in Milton Friedman, Capitalism and Freedom. Chicago: University of Chicago Press.

Greene, J. P. (2000). The effect of school choice: An evaluation of the charlotte children's scholarship fund program. Civic Report, 12, 1-15.

Howell, W. G. (2004). Dynamic selection effects in means-tested, urban school voucher programs. Journal of Policy Analysis and Management, 23(2), 225-250.

Howell, W. G., Wolf, P. J., Peterson, P. E., \& Campbell, D. E. (2000). Test-score effects of school vouchers in Dayton, Ohio, New York City, and Washington, DC: Evidence from randomized field trials. Paper presented at the annual meeting of the American Political Science Association, Washington, DC, September 2000. Available at link: https://files.eric.ed.gov/fulltext/ED445147.pdf.

Institute of Medicine and National Research Council. (2010). Student mobility: Exploring the impact of frequent moves on achievement [Summary of a workshop] (A. Beatty, Ed.). Washington, DC: National Academies Press

Mills, J. N. (2015). The effectiveness of cash transfers as a policy instrument in K-16 education (Doctoral dissertation). University of Arkansas, Fayetteville.

Mills, J. N., \& Wolf, P. J. (2016). The Effects of the Louisiana Scholarship Program on Student Achievement After Two Years. Louisiana Scholarship Program Evaluation Report\# 1. Technical Report. ERIC Clearinghouse.

Mills, J. N., \& Wolf, P. J. (2017a). The effects of the Louisiana Scholarship Program on student achievement after three years. (June 26, 2017). Louisiana Scholarship Program Evaluation Report \#7. Available at link: https://educationresearchalliancenola.org/files/publications/ Mills-Wolf-Effects-of-LSP-on-Student-Achievement-After-Three-Years.pdf

Mills, J. N., \& Wolf, P. J. (2017b). Vouchers in the bayou: The effects of the Louisiana Scholarship Program on student achievement after 2 years. Educational Evaluation and Policy Analysis, 39(3), 464-484. 
Mills, J. N., \& Wolf, P. J. (2019, April). The effects of the Louisiana Scholarship Program on student achievement after four years. EDRE working paper no. 2019-10. Social Science Research Network, April 23.

Mincberg, E. M. (2003). Vouchers and the future of public education. NYU Annual Survey of American Law, 59, 469.

Pirog, M.A. (2014). Data will drive innovation in public policy and management research in the next decade. Journal of Policy Analysis and Management, 33(2), 537-543.

Rouse, C. E. (1998). Private school vouchers and student achievement: An evaluation of the Milwaukee Parental Choice Program. The Quarterly journal of economics, 113(2), 553602.

Singer, J. D., \& Willett, J. B. (2003). Applied longitudinal data analysis: Modeling change and event occurrence. Oxford: Oxford University Press.

Stewart, T., \& Wolf, P. (2016). The school choice journey: School vouchers and the empowerment of urban families. New York: Palgrave Macmillan, 2014.

Sude, Y., DeAngelis, C. A., \& Wolf, P. J. (2018). Supplying choice: An analysis of school participation decisions in voucher programs in Washington, DC, Indiana, and Louisiana. Journal of School Choice, 1-26.

Waddington, R. J. and Berends, M. (2018), Impact of the Indiana Choice Scholarship Program: Achievement Effects for Students in Upper Elementary and Middle School. Journal of Policy Analysis and Management, 37: 783-808.

Wolf, P. J., Eissa, N., \& Gutmann, B. (2006). Who chooses, who uses? Initial evidence from the DC Opportunity Scholarship Program. Education Working Paper Archive. Available at link: https://files.eric.ed.gov/fulltext/ED509020.pdf.

Wolf, P. J., Kisida, B., Gutmann, B., Puma, M., Eissa, N., \& Rizzo, L. (2013). School Vouchers and Student Outcomes: Experimental Evidence from W ashington, DC. Journal of Policy Analysis and Management, 32(2), 246-270.

Wolf, P. J., \& Lasserre-Cortez, S. (2018). An exploratory analysis of features of New Orleans charter schools associated with student achievement growth. REL 2018-287. Washington, DC: U.S. Department of Education, Institute of Education Sciences, National Center for Education Evaluation and Regional Assistance, Regional Educational Laboratory Southwest. 